\title{
Molting of fiddler crab Uca minax megalopae: stimulatory cues are specific to salt marshes
}

\author{
Nancy J. O'Connor ${ }^{1, *}$, Michael L. Judge ${ }^{2}$ \\ ${ }^{1}$ Department of Biology, University of Massachusetts Dartmouth, 285 Old Westport Road, North Dartmouth, \\ Massachusetts 02747-2300, USA \\ ${ }^{2}$ Department of Biology, Manhattan College, 6301 Riverdale Avenue, Riverdale, New York 10471, USA
}

\begin{abstract}
Waterborne chemicals can be habitat cues for pelagic larvae of benthic invertebrates by stimulating settlement and metamorphosis. Less clear is whether cue effectiveness declines with increasing distance from the source. We examined whether the ability of seawater to stimulate metamorphosis (molting) of fiddler crab UCa minax megalopae to the first-crab stage is restricted to water overlying marshes. Laboratory-reared megalopae were enclosed in situ for $3 \mathrm{~d}$ within nylon mesh cages in both a marsh and a river site $15 \mathrm{~m}$ away from the marsh. Even in the absence of contact with sediment, megalopae in the marsh had high rates of molting, whereas those in the river molted at very low rates similar to control megalopae enclosed in glass jars containing filtered seawater and deployed in the marsh habitat. In a second experiment, we tested for a dose-dependent molting response from the presumed source of the cue. We hypothesized a negative linear relationship in molting frequency with increasing distance from the marsh. Megalopae were enclosed for $3 \mathrm{~d}$ in cages within the marsh and at distances of 2, 5, and $15 \mathrm{~m}$ away from the marsh edge, and in jars within the marsh. Molting response was greatest in the marsh, intermediate 2 and $5 \mathrm{~m}$ away from the marsh, and lowest $15 \mathrm{~m}$ from the marsh and in the control jars (test of regression slope, $F_{1,25}=13.290$, $\mathrm{p}=0.001, \mathrm{r}^{2}=0.321$ ). Therefore, chemical cues for molting of fiddler crab megalopae originate in marshes and decline in effectiveness within a short $(<15 \mathrm{~m})$ distance of the marsh habitat.
\end{abstract}

KEY WORDS: Megalopa $\cdot$ Molting $\cdot$ Fiddler crab $\cdot$ Uca minax $\cdot$ Chemical cue $\cdot$ Marsh

\section{INTRODUCTION}

Benthic marine invertebrates with indirect development have 2 life phases: planktonic larvae and benthic juveniles and adults. Each phase may have separate physiological and ecological requirements, yet the phases are linked by processes of settlement and metamorphosis. The transition from the planktonic to the benthic phase has intrigued marine ecologists for decades (e.g. Thorson 1950). Numerous studies on metamorphosis of larvae in still water conditions in the laboratory provided an abundance of information on cues that stimulate (or retard) metamorphosis (Meadows \& Campbell 1972, Crisp 1974, Scheltema 1974, Hadfield 1998, Woodin 1991). However, laboratory studies typically do not include the complex suite of factors to which larvae are exposed during dis- persal, settlement and metamorphosis in the natural environment.

Crab larvae are useful subjects for studies of settlement and metamorphosis. The culture methods for crab larvae are well developed. Metamorphosis culminates in an observable event: molting. Crab larvae are hardy; survivorship in laboratory studies is typically high, and larvae may be sampled in the field and subsequently used in laboratory experiments (Forward et al. 1994, Wolcott \& De Vries 1994, Brumbaugh \& McConaugha 1995). Furthermore, crab megalopae (the last larval stage) survive and molt in mesh cages in the natural environment, allowing placement of megalopae in various field locales with different physical and chemical conditions (O'Connor \& Judge 1997, 1999).

In prior work, we tested hypotheses on the importance of chemical cues for molting of fiddler crab 
Uca pugnax megalopae in salt marshes using caging experiments (O'Connor \& Judge 1997, 1999). Laboratory-reared megalopae in cages in salt marshes molted to the first crab stage at higher rates than sibling megalopae in laboratory or field control treatments. Cues present both in seawater and derived from marsh sediments stimulated molting, and the effects were additive; the highest molting response occurred when megalopae were exposed simultaneously to both marsh sediments and seawater overlying a marsh. The stimulatory cue in the sediment was not merely tactile, because megalopae were not stimulated to molt by marsh sediments from which the organic fraction had been removed. In addition, the longer the exposure period, the more effective the cue, yet even a $1 \mathrm{~d}$ exposure period was sufficient to stimulate molting compared to laboratory and field controls.

In the present experiments, we tested (1) whether another species of fiddler crab responds similarly to potential habitat cues, and (2) if waterborne, marshderived cues that stimulate molting of megalopae are specific to the adult habitat. We tested the molting responses of Uca minax, a species that generally occupies marshes in lower-salinity regions of estuaries than U. pugnax (Miller \& Maurer 1973, Crane 1975). We compared molting of megalopae in 2 different habitats: a salt marsh and a tidal river adjacent to the marsh, with megalopae placed at several distances from the edge of the marsh. We found that the molting responses of $U$. minax and $U$. pugnax were similar, and cues that stimulate molting in marshes declined in effectiveness within a short distance $(<15 \mathrm{~m})$ of the marsh.

\section{MATERIALS AND METHODS}

Larval culture. Megalopae used in the experiments were cultured from larvae released by ovigerous female Uca minax collected from the Taunton River estuary in Berkley, Massachusetts, USA (salinity $<10$ ppt at low tide). Individual ovigerous crabs were placed in $11.5 \mathrm{~cm}$ glass culture dishes with $\sim 200 \mathrm{ml}$ filtered $(0.45 \mu \mathrm{m})$ seawater diluted with distilled water to a salinity of 25 (= FSW). The antibiotics sodium Penicillin G $\left(21.9 \mathrm{mg} \mathrm{l}^{-1}\right)$ and streptomycin sulfate $\left(36.5 \mathrm{mg} \mathrm{l}^{-1}\right)$ were added to the seawater to decrease bacterial densities, thereby minimizing growth of the ectosymbiotic protist Vorticella sp. on adult and larval exoskeletons. Ovigerous females were transferred to clean bowls with fresh FSW and antibiotics each day until larvae hatched.

Groups of $\sim 150$ newly released sibling zoeae were placed in $20 \mathrm{~cm}$ culture dishes, each containing $\sim 750 \mathrm{ml}$ of FSW and antibiotics. Rotifers Brachionus plicatilis and newly hatched brine shrimp nauplii Artemia sp. were offered as food. As the zoeae molted to later stages, the relative proportion of Artemia sp. to rotifers in the diet was increased, so that by the fourth zoeal stage the larvae were fed brine shrimp only. Each day, the larvae were transferred to clean dishes with fresh FSW and antibiotics; food was then added. Mortality of zoeae during rearing was usually very low $(<5 \%)$, and larvae tended to molt synchronously. Larval cultures were maintained in an environmental chamber $\left(26 \pm 1^{\circ} \mathrm{C}, 14: 10 \mathrm{~h}\right.$ light:dark photoperiod).

After molting to the megalopa stage, $11 \mathrm{~d}$ after hatching, the larvae were cultured in groups of $\sim 75$ in $20 \mathrm{~cm}$ glass culture dishes containing $750 \mathrm{ml} \mathrm{FSW} \mathrm{at} \mathrm{a}$ salinity of 15 , which is more representative of Uca minax habitats (Miller \& Maurer 1973), antibiotics, and Artemia sp. nauplii. Megalopae were transferred and fed each day. Megalopae were used in field experiments $8 \mathrm{~d}$ after molting to the megalopa stage, because pilot data indicated that megalopae do not molt until then (N. J. O'Connor unpubl. data).

Field site. The field site was a Spartina alterniflora marsh growing in sandy mud sediments ( $45 \%$ particles $<63 \mu \mathrm{m})$, located on the shore of the Taunton River estuary in Berkley, Massachusetts, USA $\left(41^{\circ} 79^{\prime} \mathrm{N}\right.$, $71^{\circ} 12^{\prime} \mathrm{W}$ ). The marsh contained numerous burrows occupied by the fiddler crab Uca minax. Adjoining the marsh, toward the river's channel, was an unvegetated intertidal sandflat.

Cage design. Cylindrical cages $(10 \mathrm{~cm}$ height $\times 8.8 \mathrm{~cm}$ width) were used for field deployment of megalopae. The base of each cage consisted of the male portion $(8.8 \mathrm{~cm}$ width $\times 1.4 \mathrm{~cm}$ height) of a $100 \times 15 \mathrm{~mm}$ polystyrene petri dish (VWR 25384-070 in 1998 and Falcon 351029 in 2000). The sides and top of the cages were made of $300 \mu \mathrm{m}$ nylon mesh. The top contained a sealable flap that opened halfway to allow addition of megalopae in the field. All seams of the cages were glued with $100 \%$ silicone sealant (GE No. 012 or Dow Corning No. 8641 in 1998 and Dow Corning No. 700 Industrial Grade in 2000). Metal rods (20 cm steel tent stakes or 60D spike nails) were glued with silicone to the outside of the petri dishes to secure the cages in the marsh sediments. In the river habitat, each petri dish was glued to a $6 \mathrm{~mm} \times 4 \mathrm{~cm}$ threaded rod attached to a horizontal frame.

Treatments and cage deployment in 1998. Cages (30) placed in the marsh habitat were assigned to 1 of 3 treatments: (1) $15 \mathrm{ml}$ of surface $(\sim 0.5 \mathrm{~cm}$ depth) marsh sediment collected near fiddler crab burrows on the day the experiment began $(=$ fresh marsh sediment treatment); (2) identical marsh sediment that had been collected earlier, dried, and combusted in a muffle furnace $\left(550\right.$ to $600^{\circ} \mathrm{C}$ for $2 \mathrm{~h}$ ) to oxidize organic material (= muffled marsh sediment treatment); or (3) no sediment (= marsh without sediment treatment). Large detrital fragments and pebbles were removed from all sediment types with forceps. All sediments were placed in 
cages in the field just prior to the time megalopae were introduced to the cages; 10 sealed clear glass jars each containing $200 \mathrm{ml} \mathrm{FSW} \mathrm{(salinity} \mathrm{=} \mathrm{10)} \mathrm{and} \mathrm{lacking} \mathrm{sedi-}$ ment served as a field control treatment (= jar treatment). Jars were approximately $7 \mathrm{~cm}$ in diameter and approximately $12 \mathrm{~cm}$ high, with a polyvinyl-lined plastic lid. Nylon mesh $(300 \mu \mathrm{m})$ was wrapped around the outside of the jars to simulate light conditions inside the cages.

Within the marsh, 2 transects parallel to the shore were established in the marsh where crabs were abundant. Each transect was approximately $6.25 \mathrm{~m}$ long, at a tidal height of $0.83 \mathrm{~m}$. A total of 40 cages and jars, each separated by $30 \mathrm{~cm}$, were placed along the 2 parallel transects. Treatments alternated between fresh marsh sediment, muffled marsh sediment, no sediment and jar control treatments. All cages in the marsh were $>2.5 \mathrm{~m}$ inside the vegetated habitat.

An additional transect was established in the river habitat, parallel to the shore and $15 \mathrm{~m}$ from the marsh's edge. Cages (10) lacking sediment (= river without sediment treatment) were deployed at the same intertidal elevation as the cages in the marsh. Cages in the river habitat were attached via threaded rods to a horizontal, perforated, galvanized angle-iron $(4 \mathrm{~cm} \times 4 \mathrm{~cm}$ $\times 3 \mathrm{~m}$ long) with $30 \mathrm{~cm}$ spacing between the cages. Two $2 \mathrm{~m}$ vertical angle iron sections were driven into the river bed and secured the horizontal section at the specified tidal height (i.e. $0.83 \mathrm{~m}$ ).

Field experiments began $8 \mathrm{~d}$ after UCa minax larvae had reached the megalopa stage in laboratory cultures (12 July). In the laboratory, megalopae pooled from 4 different broods were divided into groups of 10 and placed in $12 \mathrm{ml} \mathrm{FSW}$ (salinity = 10) in polypropylene centrifuge tubes for transport to the field site. Some Artemia sp. nauplii were added to provide food for the megalopae.

We introduced 10 megalopae into each cage or control jar during early evening, $\sim 1.5 \mathrm{~h}$ prior to submersion by the incoming tide. Megalopae (and Artemia sp.) were rinsed from the centrifuge tubes into cages using sieved, field-collected seawater. Megalopae were rinsed from tubes into jars using FSW. The flap opening at the top of the cage was then sealed with silicone. In the marsh habitat, an additional empty cage contained a temperature probe (Stow Away Tidbit, Onset Computers), which sampled and recorded ambient temperature at $48 \mathrm{~s}$ intervals, and an extra jar contained a thermometer. In the river habitat, an additional cage contained a second temperature probe (Optic Stow Away, Onset Computers) which also sampled at $48 \mathrm{~s}$ intervals.

All cages were removed after $3 \mathrm{~d}$ exposure, during which they were submerged approx. $44 \%$ of the time $(28.1 \mathrm{~h}$ out of $63.8 \mathrm{~h}$ ) based on NOAA (1998) tidal predictions. In the laboratory, cages were cut open, emptied, and the contents were washed with FSW onto a
$0.4 \mathrm{~mm}$ mesh sieve. Megalopae, first-stage crabs, and sediments on the sieve were rinsed into petri dishes and examined using a lighted magnifier and a dissecting microscope. Megalopae and newly molted crabs from each cage were placed in $100 \times 15 \mathrm{~mm}$ petri dishes containing $40 \mathrm{ml} \mathrm{FSW} \mathrm{(salinity} \mathrm{=} \mathrm{10)} \mathrm{and} \mathrm{Artemia} \mathrm{sp.}$ Dishes were then placed in an environmental chamber (26 $\pm 1^{\circ} \mathrm{C}, 14: 10 \mathrm{~h}$ light:dark) and monitored $2 \mathrm{~d}$ without water exchange, by which time at least $50 \%$ of megalopae in at least 1 treatment had molted.

Treatments and cage deployment in 2000. Because the habitat effect (i.e. marsh versus river) was much larger than the effect of the sediment treatments within the marsh (see 'Results'), the experiments in 2000 focused on the role of distance from the marsh habitat in the absence of sediment. As in 1998, we used a field control treatment in the marsh habitat consisting of 7 replicate glass jars (=jar treatment) each containing $200 \mathrm{ml} \mathrm{FSW} \mathrm{(salinity} \mathrm{=} \mathrm{10)} \mathrm{and} \mathrm{no} \mathrm{sediment.}$

We established 4 transects parallel to the edge of the vegetated marsh: $2 \mathrm{~m}$ inside the marsh (= marsh treatment), $2 \mathrm{~m}$ inside the river habitat (= river $2 \mathrm{~m}$ treatment), $5 \mathrm{~m}$ inside the river habitat (= river $5 \mathrm{~m}$ treatment), and $15 \mathrm{~m}$ inside the river habitat (= river $15 \mathrm{~m}$ treatment) (Fig. 1). Cages (10 in each river treatment and 9 in the marsh) were separated by $30 \mathrm{~cm}$ within all transects and the jar control replicates were interspersed regularly along the marsh transect. Megalopae were deployed in 2 batches (from 3 different broods) at a stocking density

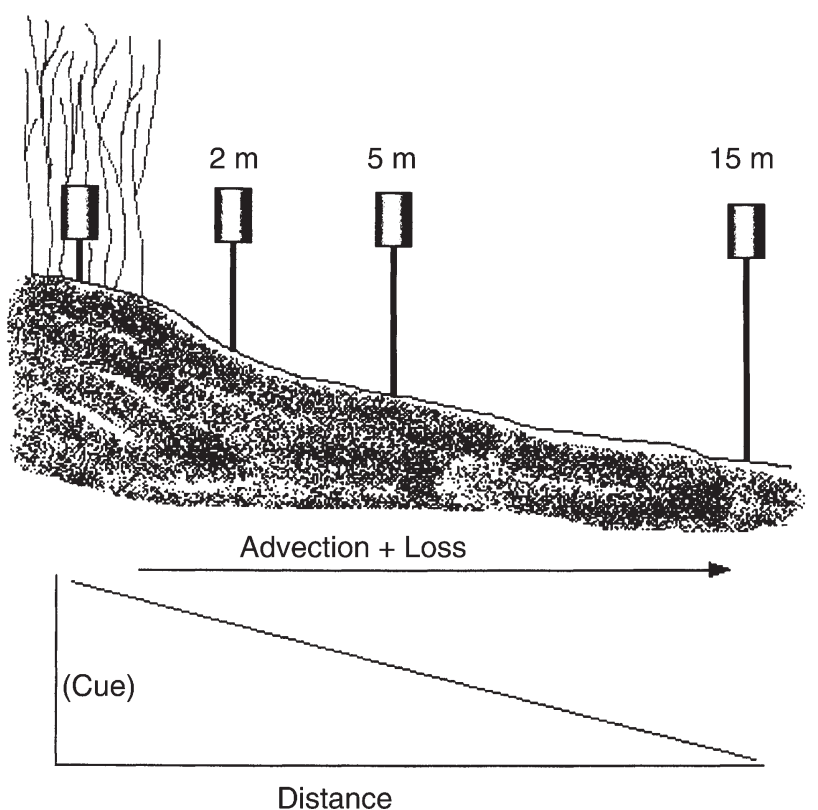

Fig. 1. Cage placement $2 \mathrm{~m}$ within marsh and 2, 5, and $15 \mathrm{~m}$ from marsh edge. Loss of effectiveness of waterborne cues in stimulating molting was modeled as a linear function of distance from marsh edge 
of 8 individuals per cage or jar. Megalopae from Batch A were deployed on 18 July, $2.0 \mathrm{~h}$ before immersion by flood tide; megalopae from Batch B were deployed on 19 July, $2.5 \mathrm{~h}$ before immersion by flood tide. Batches A and B were submerged $45 \%$ (28.6 of $63.5 \mathrm{~h}$ ) and $44.9 \%$ (28.6 of $63.7 \mathrm{~h}$ ) of the time, respectively, even though cages were deployed at identical tidal heights. In the marsh habitat, an additional empty cage contained a temperature probe (Optic Stow Away, Onset Computers), which sampled and recorded ambient temperature at $48 \mathrm{~s}$ intervals, and an extra jar contained a thermometer. A temperature probe in the river habitat $(5 \mathrm{~m})$ was lost during the experiment.

Integrity of cages was checked daily during daylight hours. Attachment failure caused the loss of 6 cages from Batch A and 5 from Batch B. Thus, the final number of replicates were: marsh $=9$, river $2 \mathrm{~m}=7$, river $5 \mathrm{~m}=4$, river $15 \mathrm{~m}=7$, jars $=7$. Cages and jars were retrieved during periods of low tide on the third day. Cage contents were processed and megalopae and first-stage crabs were scored and monitored as in the 1998 experiment.

Data analysis. The proportion molting to the firstcrab stage of those recovered alive with each replicate cage or jar was the response variable. The percentages of live individuals from recovered cages and jars were $95.2 \%$ (476 out of 500 ) and $88.6 \%$ (241 out of 272) in 1998 and 2000, respectively. The molting response was statistically analyzed on Day 12 (1998) or Day 13 (2000) of the megalopa stage, days on which $\geq 50 \%$ of the megalopae in some treatments had molted. Analysis of variance (ANOVA) could not be conducted on Day 13 data for 1998 because all megalopae in 2 treatments had molted to the first-crab stage (i.e. zero variance), which produced heterogeneity of variances. The overall treatment pattern was the same on Day 12; however, variances of treatment means were not zero. After arcsine transformation, the variances were never found to differ significantly from homogeneity (Levene's test of equality of variances, all $p$ values $>0.56$ ).

In 1998, because sediment additions were not employed in the river habitat, data were analyzed as 2 separate 1-way ANOVAs: comparison of sediment type as the main effect in the marsh habitat and comparison of habitat as the main effect without sediment present. Sediment treatment types were compared $a$ posteriori. In 2000, data were analyzed via 1-way ANOVA with distance from marsh edge as the main effect and deployment batch as a blocking factor. Deployment date was an insignificant source of variability (ANOVA, $F_{1,28}=0.595, \mathrm{p}=0.447$ ). Post-hoc comparisons (Tukey HSD) were conducted among distance treatment means. Regression analysis of all field treatments using distance from marsh edge as a predictor variable was also performed on the 2000 data.

\section{RESULTS}

\section{8 experiment}

On Day 11, some megalopae in the cages in the marsh had molted, although molting rates were low (10.4 to $38.0 \%$, depending on treatment, Fig. 2). By day 12 , megalopae in cages in the marsh containing fresh sediment or muffled sediment, and cages without sediment in the marsh had similar rates of molting, which were much higher than the molting response of megalopae in control jars in the marsh (Fig. 2, ANOVA $\left.F_{3,36}=45.272, \mathrm{p}<0.001\right)$. In addition, more megalopae in the marsh cages without sediment molted compared to megalopae in cages without sediment in the river (ANOVA $F_{1,18}=87.582, \mathrm{p}<0.001$ ). By Day 13, almost all the megalopae in all the cage treatments in the marsh had molted, yet molting frequency remained low both in the jar control in the marsh (19.1\%) and in the cages in the river $15 \mathrm{~m}$ from the marsh edge $(8.2 \%)$.

\section{0 experiment}

On Day 11, when the cages and jars were removed from the field, most megalopae in all treatments had failed to molt (Fig. 3). Molting rates had increased in all treatments by Day 12, although they were still low. By Day 13 , at least $50 \%$ of megalopae had molted in at least some treatments, and treatment differences in

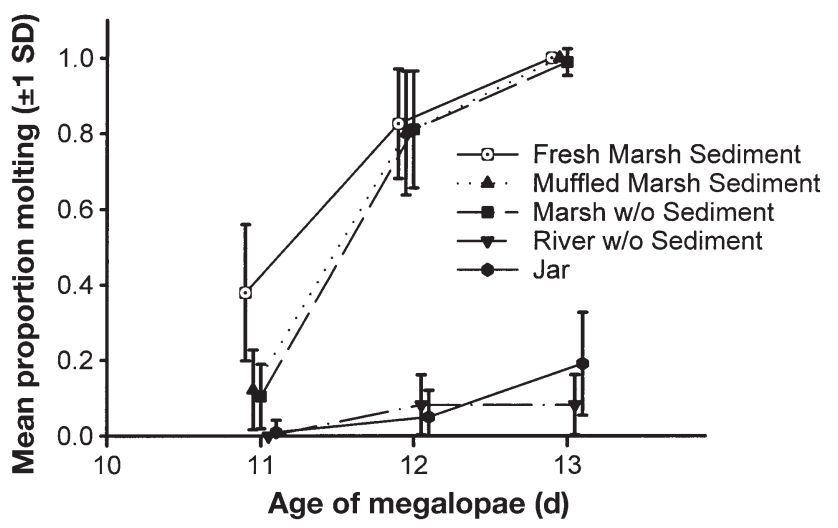

Fig. 2. Uca minax. Mean $( \pm 1 \mathrm{SD})$ proportion of megalopae molting to first-crab stage in response to sediment types in 1998 (Fresh Marsh Sediment: marsh cages containing fresh sediments collected from the vicinity of adult burrows; Muffled Marsh Sediment: marsh cages containing combusted marsh sediments; Marsh w/o Sediment: marsh cages lacking sediment; River w/o Sediment: river cages lacking sediment; Jar: control filtered seawater in sealed glass jar in marsh). Megalopae age: days since molting to megalopa stage. Treatment means and error bars offset for clarity 


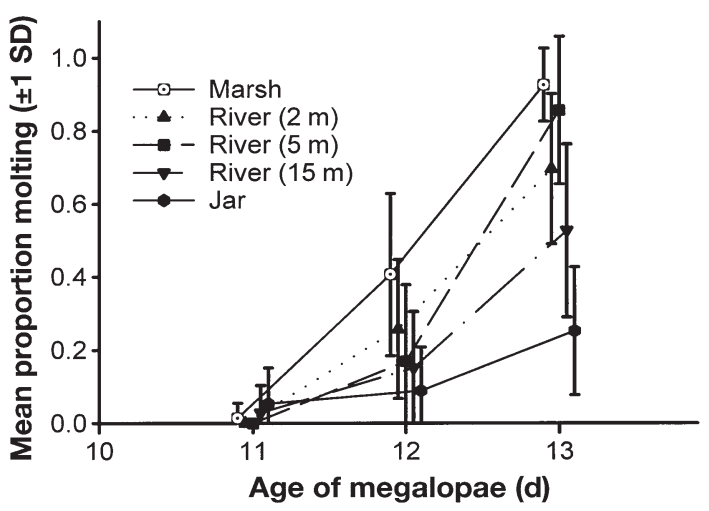

Fig. 3. Uca minax. Mean $( \pm 1 \mathrm{SD})$ proportion of megalopae molting to first-crab stage in response to distance from marsh in 2000 (Marsh: marsh cages $>2 \mathrm{~m}$ from edge; River $(2 \mathrm{~m}$ ): river cages $2 \mathrm{~m}$ from edge of marsh; River $(5 \mathrm{~m})$ : river cages $5 \mathrm{~m}$ from edge of marsh; River $(15 \mathrm{~m})$ : river cages $15 \mathrm{~m}$ from edge of marsh; Jar: control filtered seawater in sealed glass jar in marsh). Megalopae age: days since molting to megalopa stage

molting rate existed (ANOVA $F_{4,28}=13.246, \mathrm{p}<0.001$ ). More megalopae molted in the marsh than $15 \mathrm{~m}$ away from the marsh edge or in the jar controls, a result similar to that in the 1998 experiment. Molting was greater in the river $2 \mathrm{~m}$ and river $5 \mathrm{~m}$ cages than in the jar controls, and molting was greater in the river $5 \mathrm{~m}$ cages than in the river $15 \mathrm{~m}$ cage treatment. (The loss of cages at the river $2 \mathrm{~m}$ and river $5 \mathrm{~m}$ sites resulted in low replication and the inability to distinguish between the 2 treatments statistically.) Linear regression demonstrated a significant effect of increasing distance of the cages from the marsh on decreasing molting rate (Fig. 4, ANOVA on slope: $F_{1,25}=13.290, \mathrm{p}=0.001$, $\mathrm{r}^{2}=0.321$ ). A decline in molting of megalopae occurred with increasing distance from the marsh edge (proportion molting $=-0.03[$ distance $]+1.27$ )

\section{Cage temperatures}

Cage temperatures varied with the alternating pattern of intertidal exposure to air and water. During the 1998 experiments, the river cage temperature (mean $=24.4^{\circ} \mathrm{C}$; range $=15.6$ to $37.8^{\circ} \mathrm{C}$ ) was elevated relative to the marsh cage temperature (mean = $21.5^{\circ} \mathrm{C}$; range $=14.4$ to $29.8^{\circ} \mathrm{C}$ ), largely due to air temperature differences during daytime low tides (Fig. 5). However, when the cages were submerged, temperatures experienced by the megalopae in the 2 habitats were very similar. During the 2000 experiments, we only recorded cage temperatures for the marsh habitat (Fig. 6) because the temperature probe in the river was lost. Temperatures during the deployment of both megalopae batches were similar (Batch $\mathrm{A}$ mean =

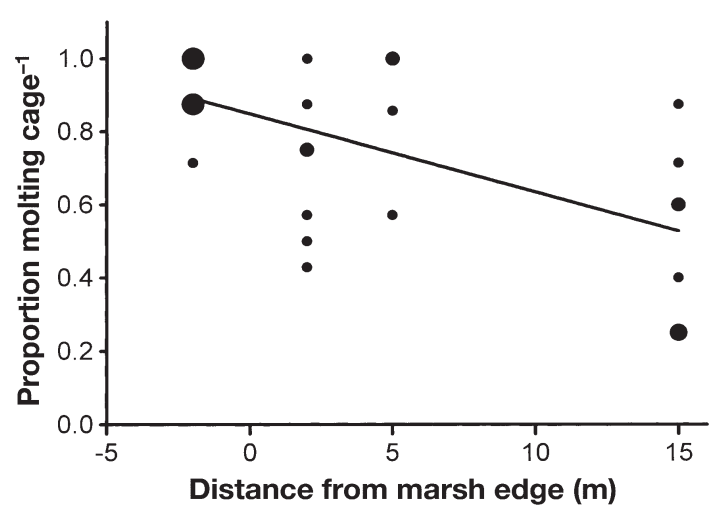

Fig. 4. Uca minax. Proportion of megalopae molting to firstcrab stage by Day 13 in cages as a function of distance from edge of a salt marsh in 2000. Cages were placed $2 \mathrm{~m}$ inside the marsh $(=-2 \mathrm{~m})$ and 2,5 , and $15 \mathrm{~m}$ from marsh edge. Symbol size is proportional to number $(1,2,3$ or 4$)$ of replicate cages; line shows best fit from linear regression analysis

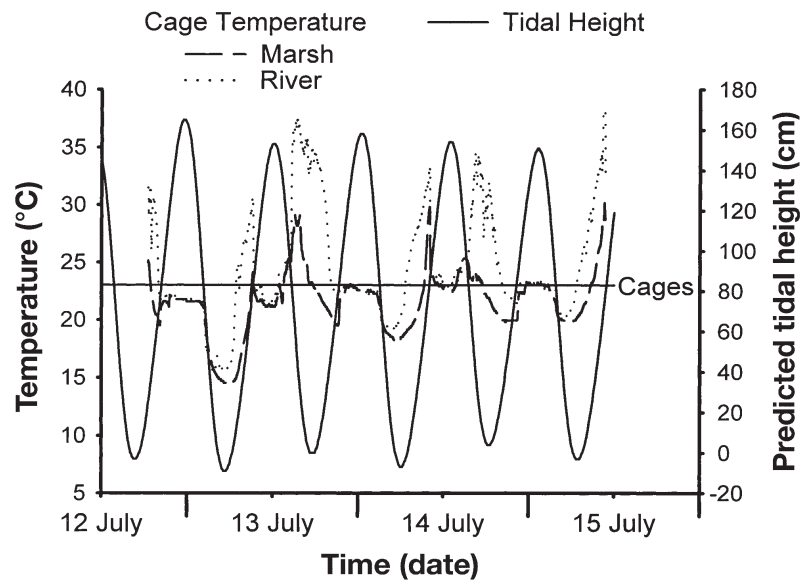

Fig. 5. Temperature in field cages and tidal height in 1998 experiment. Temperatures in marsh (dashed line) or river (dotted line) habitats were sampled every $48 \mathrm{~s}$ with a probe (Stow Away Tidbit or Optic Stow Away, Onset Computers) positioned in water retained in petri dish bottom of a cage. Predicted tidal heights (continuous line) based on Newport, Rhode Island and phase-aligned based on early night flood tide. Tidal height of field cages indicated by horizontal line

$20.7^{\circ} \mathrm{C}$ range $=12.2$ to $24.6^{\circ} \mathrm{C} ;$ Batch B mean $=20.9^{\circ} \mathrm{C}_{i}$ range $=12.2$ to $24.7^{\circ} \mathrm{C}$ ); this is important, because temperature can influence time until molting (e.g. Dawirs 1985). Overcast conditions kept the daytime air temperature low during this period.

Temperature probes in both the marsh and river responded rapidly $(<3 \mathrm{~min})$ to the increase in temperature associated with the transition from the cool evening air to the warmer flood water during the early night flood. The relatively uniform surface-water temperature brought both probe readings into agreement 


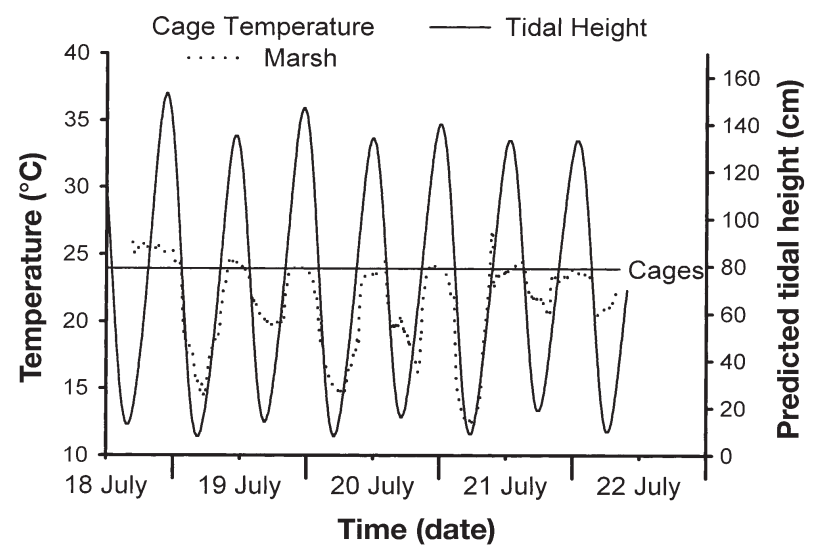

Fig. 6. Temperature in field cages and tidal height in 2000 experiment. Separate megalopae batches were deployed on 18 and 19 July. Both batches experienced $3 \mathrm{~d}$ field exposure. Temperatures in marsh (dotted line) habitat were sampled every $48 \mathrm{~s}$ with a probe (details as in Fig. 5 legend)

during cage submergence. The rapid responsiveness of the probes allowed phase alignment with tidal predictions for an NOAA tidal station (Newport, Rhode Island, USA; NOAA 1998, 2000). Thus, the temperature probe allowed calculation of submergence time. Cages were submerged $44 \%$ (28.1 of $63.8 \mathrm{~h}$ ) and $45 \%$ (28.6 of $63.5 \mathrm{~h}$ ) of the time during the experimental deployment period in 1998 and 2000, respectively.

\section{DISCUSSION}

The field-caging technique described here allowed us, in earlier work, to determine that both waterborne and sediment-associated chemical cues in salt marshes stimulate molting of Uca pugnax megalopae (O'Connor \& Judge 1997, 1999). The strong molting response of the megalopae led us to test, in the present experiments, whether the waterborne cue alone was specific to the marsh itself and lost its effectiveness at short distances from the marsh. We addressed this question by examining molting of fiddler crab megalopae in both a marsh and an adjacent tidal river. The use of the fiddler crab $U$. minax, which inhabits a region of estuaries with low wave energy, facilitated successful deployment of cages in an unvegetated, structurally simple habitat.

Stimulatory cues for molting were highly specific to salt marshes. Within as small a distance as $15 \mathrm{~m}$, fiddler crab megalopae did not respond to the adult habitat (Figs. 2 \& 3). The experiment in 2000 was designed to test the distance from the marsh over which the cue would be effective in stimulating molting of megalopae. The high molting response of Uca minax megalopae in cages without sediment (Fig. 2) demonstrated that any tactile cue was secondary in importance to a waterborne cue. We hypothesized that the source of the waterborne cue was the marsh, and that the cue would diffuse into the seawater during flood tide, and be transported out of the marsh during ebb tide. The concentration of the cue would decrease with increasing distance from the marsh due to advection, turbulent mixing, and diffusion in creeks and rivers adjacent to the marsh (Zimmer \& Butman 2000). Unfortunately, loss of cages at the 2 and $5 \mathrm{~m}$ sites did not allow us to distinguish molting responses at those sites using ANOVA. However, regression analysis showed a significant decline in molting with increasing distance from the marsh (Fig. 4). We assumed a linear loss in effectiveness of the cue with increasing distance from the marsh, although exponential decay, such as an advection-diffusion model with turbulent mixing, might be more appropriate for benthic flow environments (Nowell \& Jumars 1984). In our analysis, nonlinear regression analysis did not produce better predictions of decline in molting with increasing distance from the marsh edge. For example, simple regression models using exponential decay ( $\mathrm{e}^{\text {distance }}$ ) or reciprocal of distance $\left(\right.$ distance $^{-1}$ ) explained a smaller fraction of the molting rate decline $\left(\mathrm{r}^{2}=0.276\right.$ and 0.142 , respectively). Nonetheless, the specificity of waterborne cues to the marsh habitat was pronounced (Figs. $3 \& 4$ ).

Our experimental design did not allow us to determine whether the reduction in molting in the river habitat was also related to an effect of increased distance above the benthos, because cages in the river were at least $1 \mathrm{~m}$ higher above the sediment than those in the marsh. It is possible that the cue is a common molecule produced in benthic sediments, such as ammonia; however, ammonia inhibits molting in blue crab megalopae (Forward et al. 1997). In addition, fiddler crab megalopae settle in vegetated salt marshes whilst avoiding settling in mudflats only $1 \mathrm{~m}$ away from the edge of the marsh (O'Connor 1993). This suggests that the waterborne cue is, in fact, derived from the marsh itself. Krug \& Zimmer (2000) found that water collected from a patch of intertidal host algae contained substances that stimulated metamorphosis of a herbivorous opisthobranch mollusc. Water trapped within the algae mat at low tide accumulated substances that were present above the mat shortly after it was flooded. The effectiveness of the substances at stimulating metamorphosis declined both with time after immersion and distance from the patch. An analogous situation might occur with substances that stimulate molting of fiddler crab megalopae in marshes.

Waterborne chemical cues also stimulate molting of megalopae of other species of crab. Marsh grass, seagrasses, and some species of macroalgae reduce the time to molt in blue crab Callinectes sapidus mega- 
lopae (Forward et al. 1994, 1996, Brumbaugh \& McConaugha 1995). Macroalgae also stimulate molting of the xanthid Panopeus herbstii (Weber \& Epifanio 1996) and the grapsid Chasmagnathus granulata (Gebauer et al. 1998). In addition, chemical cues derived from conspecific adults stimulate molting of megalopae of several taxonomically different crab species (Forward et al. 2001, Kopin et al. 2001).

For the fiddler crabs UCa pugnax and U. minax, molting rates were similar; after a 3 d exposure period, relatively few megalopae had molted, and molting increased dramatically during the next $2 \mathrm{~d}$. The major difference was the absolute age of the megalopae when molting commenced. Molting in U. minax occurred a few days later than in $U$. pugnax in both control and experimental treatments, probably because $U$. minax megalopae require more time to become competent to molt (N. J. O'Connor unpubl. data). For this reason, field exposure began $8 \mathrm{~d}$ after larvae had molted to the megalopa stage for $U$. minax, rather than $6 \mathrm{~d}$ as was the case for $U$. pugnax (O'Connor \& Judge 1997, 1999).

The results of the present study clearly demonstrate that cues derived from the habitat of juvenile and adult fiddler crabs stimulate molting of megalopae, and that the cues are effective only within or at a short distance $(<15 \mathrm{~m})$ from the adult habitat. The cue(s) might be produced by a marsh organism, including adult fiddler crabs (O'Connor \& Gregg 1998). During marsh flooding, these cues would be released into the water and stimulate molting of megalopae entering the marsh. Even though molting might not occur immediately, megalopae remaining on the marsh during the subsequent ebb tide would continue to be exposed to the cue during the next flooding tide. Future studies should determine the source of the cue, and its effects on megalopa behavior. For instance, Callinectes sapidus megalopae avoid settling on textured megalopae collectors that contain adult fiddler crabs Uca pugilator and U. pugnax or mud crabs Panopeus herbstii, which prey on blue crab megalopae in the laboratory (Welch et al. 1997). The interplay of behavior and molting of crab megalopae should be a fruitful avenue of research.

Acknowledgements. We are grateful to our students for their work in the laboratory and field: D. Barrett, M. Brandhagen, S. Cabral, A. Gregg, J. Klein, C. Marshall, D. Pimentel and B. Tieu Van. We also thank the residents of Bayview Shores, Berkley, Massachusetts, for allowing us to perform the experiments on their property.

\section{LITERATURE CITED}

Brumbaugh RD, McConaugha JR (1995) Time to metamorphosis of blue crab Callinectes sapidus megalopae: effects of benthic macroalgae. Mar Ecol Prog Ser 129:113-118
Crane J (1975) Fiddler crabs of the world. Princeton University Press, Princeton, NJ

Crisp DJ (1974) Factors influencing the settlement of marine invertebrate larvae. In: Grant PT, Mackie AM (eds) Chemoreception in marine organisms. Academic Press, New York, p 177-265

Dawirs RR (1985) Temperature and larval development of Carcinus maenas (Decapoda) in the laboratory; predictions of larval dynamics in the sea. Mar Ecol Prog Ser 24: 297-302

Forward RB Jr, Frankel DAZ, Rittschof D (1994) Molting of megalopae from the blue crab Callinectes sapidus: effects of offshore and estuarine cues. Mar Ecol Prog Ser 113:55-59

Forward RB Jr, De Vries MC, Rittschof D, Frankel DAZ, Bischoff JP, Fisher CM, Welch JM (1996) Effects of environmental cues on metamorphosis of the blue crab Callinectes sapidus. Mar Ecol Prog Ser 131:165-177

Forward RB Jr, Tankersley RA, Blondel D, Rittschof D (1997) Metamorphosis of the blue crab Callinectes sapidus: effects of humic acids and ammonium. Mar Ecol Prog Ser 157:277-286

Forward RB Jr, Tankersley RA, Rittschof D (2001) Cues for metamorphosis of brachyuran crabs: a review. Am Zool 41: 1108-1122

Gebauer P, Walter I, Anger K (1998) Effects of substratum and conspecific adults on the metamorphosis of Chasmagnathus granulata (Dana) (Decapoda: Grapsidae) megalopae. J Exp Mar Biol Ecol 223:185-198

Hadfield MG (1998) The DP Wilson lecture. Research on settlement and metamophosis of marine invertebrate larvae: post, present and future. Biofouling 12:9-29

Kopin CY, Epifanio CE, Nelson S, Stratton M (2001) Effects of chemical cues on metamorphosis of the Asian shore crab Hemigrapsus sanguineus, an invasive species on the Atlantic coast of North America. J Exp Mar Biol Ecol 265: 141-151

Krug PJ, Zimmer RK (2000) Larval settlement: chemical markers for tracing production, transport, and distribution of a waterborne cue. Mar Ecol Prog Ser 207:283-296

Meadows PS, Campbell JI (1972) Habitat selection by aquatic invertebrates. Adv Mar Biol 10:271-382

Miller KG, Maurer D (1973) Distribution of fiddler crabs, Uca pugnax and Uca minax, in relation to salinity in Delaware rivers. Chesapeake Sci 14:219-221

NOAA (National Oceanic and Atmospheric Administration) (1998) Tide tables, high and low water predictions, east coast of North and South America, including Greenland. US Department of Commerce, Washington, DC

NOAA (National Oceanic and Atmospheric Administration) (2000) Tide tables, high and low water predictions, east coast of North and South America, including Greenland. US Department of Commerce, Washington, DC

Nowell ARM, Jumars PA (1984) Flow environments of aquatic benthos. Annu Rev Ecol Syst 15:303-328

O'Connor NJ (1993) Settlement and recruitment of the fiddler crabs Uca pugnax and U. pugilator in a North Carolina, USA, salt marsh. Mar Ecol Prog Ser 93:227-234

O'Connor NJ, Gregg AS (1998) Influence of potential habitat cues on duration of the megalopal stage of the fiddler crab Uca pugnax. J Crustac Biol 18:700-709

O'Connor NJ, Judge ML (1997) Flexibility in timing of molting of fiddler crab megalopae: evidence from in situ manipulation of cues. Mar Ecol Prog Ser 146:55-60

O'Connor NJ, Judge ML (1999) Cues in salt marshes stimulate molting of fiddler crab Uca pugnax megalopae: more evidence from field experiments. Mar Ecol Prog Ser 181: 131-139 
Scheltema RS (1974) Biological interactions determining larval settlement of marine invertebrates. Thalassia Jugosl 10:263-296

Thorson G (1950) Reproductive and larval ecology of marine bottom invertebrates. Biol Rev 25:1-45

Weber JC, Epifanio CE (1996) Response of mud crab (Panopeus herbstii) megalopae to cues from adult habitat. Mar Biol 126:655-661

Welch JM, Rittschof D, Bullock TM, Forward RB Jr (1997) Effects of chemical cues on settlement behavior of blue

Editorial responsibility: Otto Kinne (Editor), Oldendorf/Luhe, Germany crab Callinectes sapidus postlarvae. Mar Ecol Prog Ser 154:143-153

Wolcott DL, De Vries MC (1994) Offshore megalopae of Callinectes sapidus: depth of collection, molt stage, and response to estuarine cues. Mar Ecol Prog Ser 109: $157-163$

Woodin SA (1991) Recruitment of infauna: positive or negative cues? Am Zool 31:797-807

Zimmer RK, Butman CA (2000) Chemical signaling processes in the marine environment. Biol Bull 198:168-187

Submitted: November 13, 2003; Accepted: June 8, 2004

Proofs received from author(s): October 26, 2004 